\title{
Impact of Financial Inclusion for Welfare : Analyze to Household Level
}

\author{
Multazam Mansyur Addury \\ Universitas Gadjah Mada Indonesia \\ multazam.mansyur@gmail.com
}

\begin{abstract}
One indicator of poverty in a country is still low access to financial facilities to the community. Therefore, a program of massive financial inclusion is currently being campaigned. Financial inclusion is a program that provides easy access to finance (savings and financing) to the community so that it can improve welfare. This study analyzes the part of financial inclusion, namely the influence of the amount of credit and deposits/investments on household income, household consumption expenditure, and household living facilities. The data is taken from the Indonesian Family Life Survey in the period 2000, 2007 and 2014. This research uses panel data regression analysis. The results of the study found that (a) there is a significant effect of the amount of credit on household income, (b) there is a significant influence on the amount of credit and savings/investments on household consumption expenditures, and (c) there is no significant effect on the amount of credit and savings or investment household residence facilities.
\end{abstract}

Keywords: Financial Inclusion, Welfare, Household Income, Indonesian Family Life.

\section{A. INTRODUCTION}

Financial crisis that occurred in 1998 and 2008 gave the great impact to people and financial system. Since that crisis, financial inclusion term was programmed regarding the deep impact on people in the bottom of the pyramid who are people with low and irregular income, living in remote areas, disabled people, workers with no legal identity documents and marginalized communities (www.bi.go.id, 2017). Basically, financial inclusive policy is a financial service deepening addressed to lower classes society to use formal financial products and services such as safe keeping, transfering, saving or loan and insurance. Financial inclusive policy was implemented not only by providing financial products but also by combining it with other aspects. Financial inclusion is expected to provide convenience for the community to take advantage of financial services provided by banks. It can encourage people to save their money and take the financial services provided by the banking system.

A healthy and dynamic economy requires financial system which able to channel funds efficiently from people with more funds to communities with productive investment 
Journal of Finance and Islamic Banking | Vol. 1 No. 2, July-December 2018

opportunities (Mishkin, 2008). Financial inclusion is expected to increase people welfare in which they participate in using banking fiancial services. Undang-Undang No. 11/2009 explains that social welfare is the condition where material, spiritual, and social needs of citizens have been satisfied in order to live properly and able to develop themselves, so they can carry out their social functions.

Related to the context of Islamic economics studies, welfare is one of the main objectives reflected in the concept of maqashid shari'ah which consists of maintaining religion (Hifdzud-Diin), nurturing the soul (Hifdzun-Nafs), maintaining the mind (Hifdzul-Aql), maintaining heredity (Hifdzun-Nasl), and keeping the treasure (Hifdzul-Maal). In maqashid shari'ah, every human being is encouraged to satisfy his welfare based on five aspects, those are religion, soul, mind, heredity, and treasure. Badawi (1982) explained in "Mu'jam Musthalahâtu al- 'Ulûm al-Ijtimâ'iyyah” that social welfare is the system that regulates social services and institutions to help individuals and groups in achieving a level of life and decent health, in which aimed to gain equal social relation among individuals according to their capabilities to grow and to enhance the dignity of their lives.

Central Bureau of Statistics (Badan Pusat Statistik/BPS) Indonesia (2015) showed there are 8 indicators of public welafre, those are income, family expenditure, living conditions, residential facilities, family health, the easiness access to health services, the easiness access to children education, and the easiness access to get transportation facilities. Based on the exposure above, the author was interested to conduct this research that aimed to determine the impact of financial inclusion on the public welfare by using household level analysis. This research contributes to give additonal discussion about financial inclusion. The measurements of financial inclusion are level of credits/financing and level of savings/investment on household welfare measured by using 3 approaches they are household income, household expenditure, and household vehicles.

\section{A.1. Welfare}

According to the BPS (2005), the indicators used to determine the level of well-being are eight, namely income, consumption or family expenses, conditions of residence, living facilities, health of family members, ease of obtaining health services, ease of entering children into education, and ease of obtaining transportation facilities. Meanwhile, Islam divides the dimensions of well-being into two parts. First, holistic and 
balanced welfare, which includes both material and spiritual dimensions and includes both individuals and social. Human figure consisting of physical and mental elements, therefore happiness must be balanced between the two. Likewise humans have individual dimensions, but of course they cannot be separated from the social environment. Thus humans will feel happy if there is a balance between themselves and their social environment.

Second, welfare in the world and in the hereafter. Humans not only live in the world of nature but also in the hereafter. If the ideal conditions cannot be achieved, the welfare of the hereafter is certainly preferred, because it is a life that is in all respects more valuable. Therefore, the general term that is widely used to describe a condition of life that is materially spiritual in the life of the world and in the hereafter in the teachings of Islam is Falah. Falah is glory and victory in life (Anto, 2003: 6).

Welfare in socio-economic development, cannot be defined only based on materialist and hedonic concepts, but also includes humanitarian and spiritual goals (Hafiduddin, 2002). Islam teaches a balance between individual economic freedom with justice and shared prosperity. In this context, the presence of the state is needed to ensure that every citizen is able to meet standard living needs.

\section{A.2. Financial Inclusion}

The terms financial inclusion or financial inclusion became a trend after the 2008 crisis. That was because it had a crisis impact on groups in the bottom of the pyramid. The bottom of pyramid group is an irregular low income group, living in remote areas, disabled people, workers who do not have legal identity documents, and marginalized communities. They are generally unbanked and are recorded very high outside developed countries. Although they are thought to have no savings, they can be trusted among them to have unproductive movable objects (such as gold, land). This object can be cashed and used for productive purposes such as for non-formal micro business capital. Arriving at this thought sometimes they forget that by cashing in these objects is expected to be one way to solve the problem. Especially if they are assisted and fostered (Miraza, 2014).

Financial inclusion is the right of every person to have full access and service from financial institutions in a timely, convenient, informative and affordable manner, with full respect for dignity and dignity. On the other hand, financial inclusion is defined as all efforts aimed at eliminating all price and non-price barriers to provide access to the public 
Journal of Finance and Islamic Banking | Vol. 1 No. 2, July-December 2018

in utilizing financial services. This inclusive finance is a national strategy to encourage economic growth through equal income, poverty alleviation and financial system stability (Bank Indonesia, 2014). Financial inclusion is the right of every person to have full access and service from financial institutions in a timely, convenient, informative and affordable manner, with full respect for dignity and dignity. The participation of financial institutions in developing financial inclusion appropriately is by developing a program that does not only rely on businesses to raise savings or credit with low interest, but must actively participate in alleviating poverty through family development with wider access to credit for poor families.

Financial Inclusion is not just a banking institution, not just getting credit. But it is more about how those who have never saved, never use credit facilities are given the opportunity to save and get credit in accordance with President's instruction Number 3 of 2010 concerning pro-people development programs. This is in line with the national vision of Financial Inclusion, which is to realize a financial system that can be accessed by all levels of society to encourage economic growth, poverty alleviation, income equity, and the creation of financial system stability in Indonesia (Bank Indonesia, 2014).

\section{A.3. The Relation of Credits and Savings to Houeshold Income, Household Expanditure, and Household Vehicles}

There were some researches that had discussed about financial inclusion. First, Ugwuanyi (2012), aimed to find out the factors that encourage households to access credit and the impact of credit access to household welfare. The household welfare in this study would be measured by using the level of per capita consumption expenditure. The results found that access to credit had a positive effect on household welfare as measured by using per capita consumption expenditure rate. Research by Sengsourivong dan Mieno (2014) aimed to find out the impact of Saving and Credit Union (SCU) on household welfare. The result found that Saving and Credit Union (SCU) had a significant effect to increase level of income, expenditure, and household assets. Okereke (2011) conducted a research that aimed to find out the impact of financial deepening on aggregat welfare in Nigeria. Financial deepening in Okereke's research (2011) was measured by using two variables they were intermediation/financial deelopment (MS2/GDP) and private sector credit ratio in gross domestic product (PSC/PDB), whereas welfare was measured by using household 
Impact of Financial Inclusion for Welfare : Analyze to Household Level

per capita expenditure. The results of the study found that financial deepening has no significant effect on aggregate welfare.

Then, the research conducted by Setyari (2012) aimed to evaluate the impact of microcredit on household welfare in Indonesia. Variable of welfare was measured by using 3 indicators, those are household consumption expenditue, children education, and household labor supply with micro credit facility. The result of that research was microcredit had positive impact on the level of household welfare in Indonesia in terms of increasing per capita expenditure and labor supply in households receiving microcredit. However, at the level of children's education, there was no significant impact of microcredit.

The amount of credit and savings/investments are two indicators used to measure the level of financial inclusion of operational activities performed by financial institutions. Following a policy of financial inclusion, it is hoped that the public can easily utilize financial services. Loans disbursed by financial institutions are expected to increase household income. Credit is divided into three types: consumer loans, working capital loans, and investment loans. The three types of credit, can be utilized by every household to increase its income either by utilizing credit as working capital and as investment, or utilizing credit with consumptive purpose. Savings and investments made by households can also be a source of household income.

On disbursed credit by financial institutions, credit with consumption purpose has bigger portion than credit with investment purposes. It can be concluded that the portion of consumer credit can increase household consumption expenditure. Coupled with increased consumption expenditure due to an increase in income from households that utilize saving/investment facilities from financial institutions. Furthermore, credit provided by financial institutions is also closely related to the number of residential facilities owned by households. The existence of a credit allows households to buy goods at the present time and pay it off in the future, but it does not mean that a credit facility encourages households to purchase more goods, because they have to pay with their income future (Suparmoko, 2001). Households will consider several things in making payment with credit service, such as interest rate, down payment, repayment term. It also happened in public savings/investment facilitated by financial institutions. The profit from the invesment can be used to purchase residential facilities, while household savings can be used to purchase goods for residential facilities in the future. 
Picture 1. Research Concept

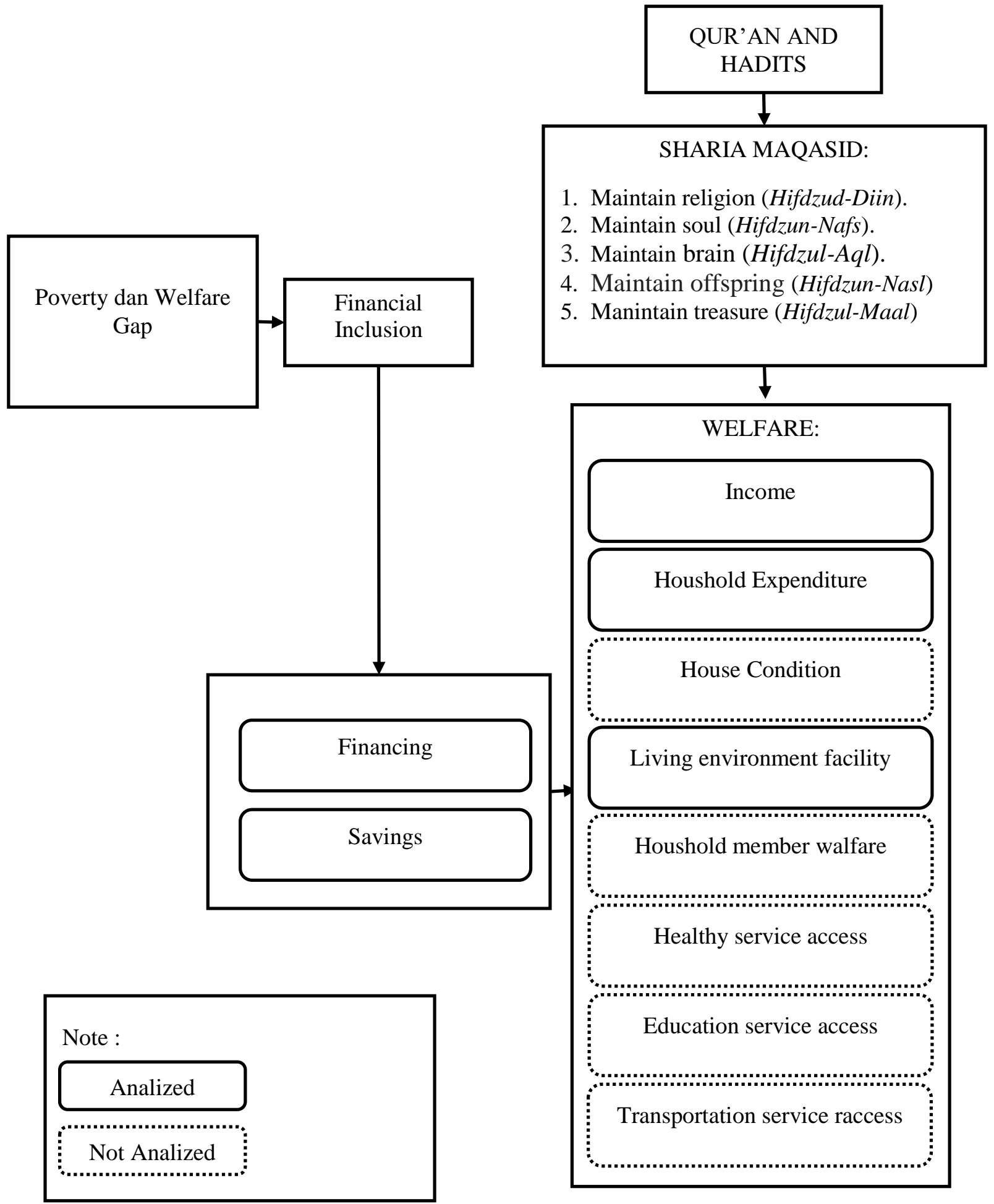

\section{B. DATA AND METHOD}

\section{B.1. Data Collection}

The data research use Indonesian Family Life Survey (IFLS) data in the period of 2000, 2007, and 2014. Independent variabel use IFLS data in the period of 2000 and 2007, while dependent variabel will use IFLS data in 2007 and 2014. The use of different periods 
between independent variables and dependent variables is intended to answer the question that whether credit and savings/investments given in the previous period can affect the welfare of households in the following period.

\section{B.2. Data Analysis}

Financial inclusion data is measured by using 2 variables, those are credit amount and saving/invesment amount. While, welfare is measured by using 3 variables those are household income, household expenditure, and living facilities. Before analyzing those 5 variables, first it should be transformed to natural logarithm. Then, to find out the impact of financial inclusion on public welfare, the author used the method of regression analysis of panel data. Equations model are as follow:

$$
\begin{aligned}
& \log (\text { Incm })_{i t}=\propto+\beta_{1} \log (X 1)_{i t}+\beta_{2} X 2_{i t}+\epsilon_{i t} \\
& \log (\text { Expnd })_{i t}=\propto+\beta_{1} \log (X 1)_{i t}+\beta_{2} X 2_{i t}+\epsilon_{i t} \\
& \log (\text { Fclty })_{i t}=\propto+\beta_{1} \log (X 1)_{i t}+\beta_{2} X 2_{i t}+\epsilon_{i t}
\end{aligned}
$$

\footnotetext{
Annotation :

Incm = household income

Expend = household expenditure

Fclty = Living Facility

X1 = Independent variables, consist of:

- Credit/financing

- Savings/investment
}

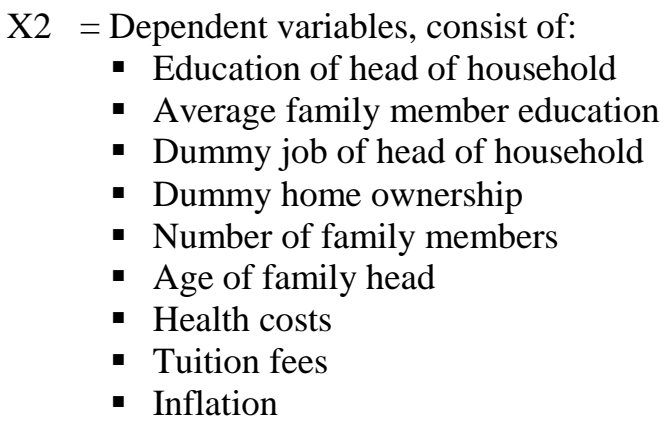

- Inflation

Another phase of data analysis is the classic assumption test. The classic assumption test is conducted to find out the existence of an association with the independent variable. The classic assumption test that will be used is the multicollinearity test and heteroscedasticity test. The next step after panel regression is multiple linear regression analysis, model accuracy test ( $\mathrm{F}$ and $\mathrm{R}^{2}$ test ), and t test.

\section{B. RESULT AND DISCUSSION}

\section{C.1. Panel Data Regression}

Based on the result of model fitting test, it is known in the equation of ln_income using the common effect model. This is because the result of Chow Test and LM Test conclude such result. In the ln_expend equation, Chow Test, Hausman Test, and LM Test 
Journal of Finance and Islamic Banking $\mid$ Vol. 1 No. 2, July-December 2018

find different results from each other, but researcher will use random effect model. This is based on the opinion from Gujarati (2003) which explains that if $\mathrm{N}$ is large and $\mathrm{T}$ small, and if the underlying assumption of random effect can be fulfilled, then the random effect model will be more efficient than the fixed effect model. Next in the equation of ln_facltie will use fixed effect model due to the result of Chow Test and Hausman Test concluding the result with fixed effect model. Furthermore, the results of panel data regression test will be presented in the following table:

Table 1. Result of Regression Estimate

\begin{tabular}{|c|c|c|c|c|c|c|}
\hline VARIABLES & 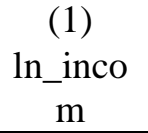 & $\begin{array}{c}\text { (2) } \\
\text { ln_incom }\end{array}$ & $\begin{array}{c}(3) \\
\ln \_ \text {expen } \\
d\end{array}$ & $\begin{array}{c}(4) \\
\ln \_ \text {expen } \\
d\end{array}$ & $\begin{array}{c}(5) \\
\ln \_ \text {facltie }\end{array}$ & $\begin{array}{c}(6) \\
\ln \_ \text {faclti } \\
\text { e }\end{array}$ \\
\hline ln_crdt & $\begin{array}{r}0,304 * \\
* * \\
(0,030)\end{array}$ & $\begin{array}{r}0,164 * * * \\
(0,032)\end{array}$ & $\begin{array}{r}0,199 * * * \\
(0,021)\end{array}$ & $\begin{array}{r}0,091 * * * \\
(0,021)\end{array}$ & $\begin{array}{r}0,266^{* *} \\
(0,101)\end{array}$ & $\begin{array}{r}0,024 \\
(0,138)\end{array}$ \\
\hline ln_invst & $\begin{array}{r}0,166 * \\
* * \\
(0.031)\end{array}$ & $0,110 * * *$ & $0,119 * * *$ & $0,062 * * *$ & $\begin{array}{r}-0,042 \\
(0091)\end{array}$ & $\begin{array}{r}0,013 \\
0,008)\end{array}$ \\
\hline Educhead & & $\begin{array}{r}0,062 * * * \\
(0,015)\end{array}$ & & $\begin{array}{r}0,012 \\
(0,010)\end{array}$ & & $\begin{array}{r}0,136 \\
(0,225)\end{array}$ \\
\hline Rtaeduc & & $\begin{array}{r}0,033 \\
(0,025)\end{array}$ & & $\begin{array}{l}0,030^{*} \\
(0,017)\end{array}$ & & $\begin{array}{r}0,135 \\
(0,196)\end{array}$ \\
\hline Jobhead & & $\begin{array}{r}0,853 * * * \\
(0,197)\end{array}$ & & $\begin{array}{r}0,003 \\
(0,101)\end{array}$ & & $\begin{array}{c}0,940 * \\
(0,541)\end{array}$ \\
\hline Hostat & & $\begin{array}{r}-0,236 \\
(0,209)\end{array}$ & & $\begin{array}{r}0,078 \\
(0,155)\end{array}$ & & $\begin{array}{r}-0,028 \\
(0,842)\end{array}$ \\
\hline Hhsize & & $\begin{array}{r}0,036 \\
(0,025) \\
-0,029 * *\end{array}$ & & $\begin{array}{r}0,042 * * * \\
(0,015) \\
-0,019 * *\end{array}$ & & $\begin{array}{r}0,431 \\
(0,406)\end{array}$ \\
\hline Age & & $\begin{array}{r}* \\
(0,007)\end{array}$ & & $\begin{array}{r}* \\
(0,005)\end{array}$ & & $\begin{array}{r}0,027 \\
(0,226)\end{array}$ \\
\hline ln_costhealt & & $\begin{array}{r}0,037 \\
(0,027)\end{array}$ & & $\begin{array}{r}0,098 * * * \\
(0,018)\end{array}$ & & $\begin{array}{r}-0,026 \\
(0,111)\end{array}$ \\
\hline ln_costeduc & & $\begin{array}{l}0,078^{*} \\
(0,042)\end{array}$ & & $\begin{array}{r}0,132 * * * \\
(0,029)\end{array}$ & & $\begin{array}{l}-0,080 \\
(0,172)\end{array}$ \\
\hline City & & $\begin{array}{r}0,040 \\
(0,094)\end{array}$ & & $\begin{array}{r}0,007 \\
(0,065)\end{array}$ & & $\begin{array}{r}-0,764 \\
(0,955)\end{array}$ \\
\hline Infl & & $\begin{array}{r}0,141 * * \\
(0,061)\end{array}$ & & $\begin{array}{r}0,223 * * * \\
(0,042)\end{array}$ & & $\begin{array}{r}0,162 \\
(1,058)\end{array}$ \\
\hline Constant & $\begin{array}{r}9,895 * \\
* * \\
(0,439)\end{array}$ & $\begin{array}{r}9,732 * * * \\
(0,683)\end{array}$ & $\begin{array}{r}10,073 * * \\
* \\
(0,316)\end{array}$ & $\begin{array}{r}7,792 * * * \\
(0,472)\end{array}$ & $\begin{array}{r}12,920 * * \\
* \\
(1,420)\end{array}$ & $\begin{array}{r}9,343 \\
(7,600)\end{array}$ \\
\hline Observations & 443 & 350 & 528 & 402 & 515 & 395 \\
\hline Prob > F & 0,000 & 0,000 & 0,000 & 0,000 & 0,028 & 0,025 \\
\hline R-squared & 0,35 & 0,53 & 0,20 & 0,28 & 0,13 & 0,50 \\
\hline
\end{tabular}

Source: Data Processed

C.2. The Influence of Credit Amount and Savings/Investment on Household Income 
The result of research on the influence of credit/financing and saving/investment to household income shows that there is positive and significant amount of credit/financing to household income. This is seen from the regression coefficient value 0.164 and the significance level 0.000 ( $\mathrm{p}<0.05$ ). The positive influence of credit/financing on household income means that when a household utilize the credit facilities from a financial institution, it will increase the household income.

Furthermore, this research also found that there is a positive and significant influence of saving/investment to household income. This is evidenced by the regression coefficient value of 0.110 and the significance level of 0.000 ( $p>0.05)$. It means that when people make deposits or investments into financial institutions, it will have an impact on the increase in household income. The results of this research are in accordance with the findings of Sengsourivong and Mieno (2014) who found the impact of Credit and Saving Union (CSU) on increasing income in Laos.

Household that utilizes the credit facilities of financial institutions can increase the number of its production factors. This production factor can then increase household income. According to Boediono (2002), income can be influenced by several factors as follows:

a) The number of owned production factors that have been derived from the results of this year's savings and inheritance or grant.

b) Price per unit of each factor of production, this price is determined by supply and demand in the production factor market.

c) The results of the activities of family members as a side job.

One of the factors causing the significant influence of credit on household income is the portion of credit with the purpose of working capital utilized by society is very high. This can be seen in the following figure. 
Journal of Finance and Islamic Banking $\mid$ Vol. 1 No. 2, July-December 2018

Figure 1. Portion of Banking Loans in 2007 and 2014 Period

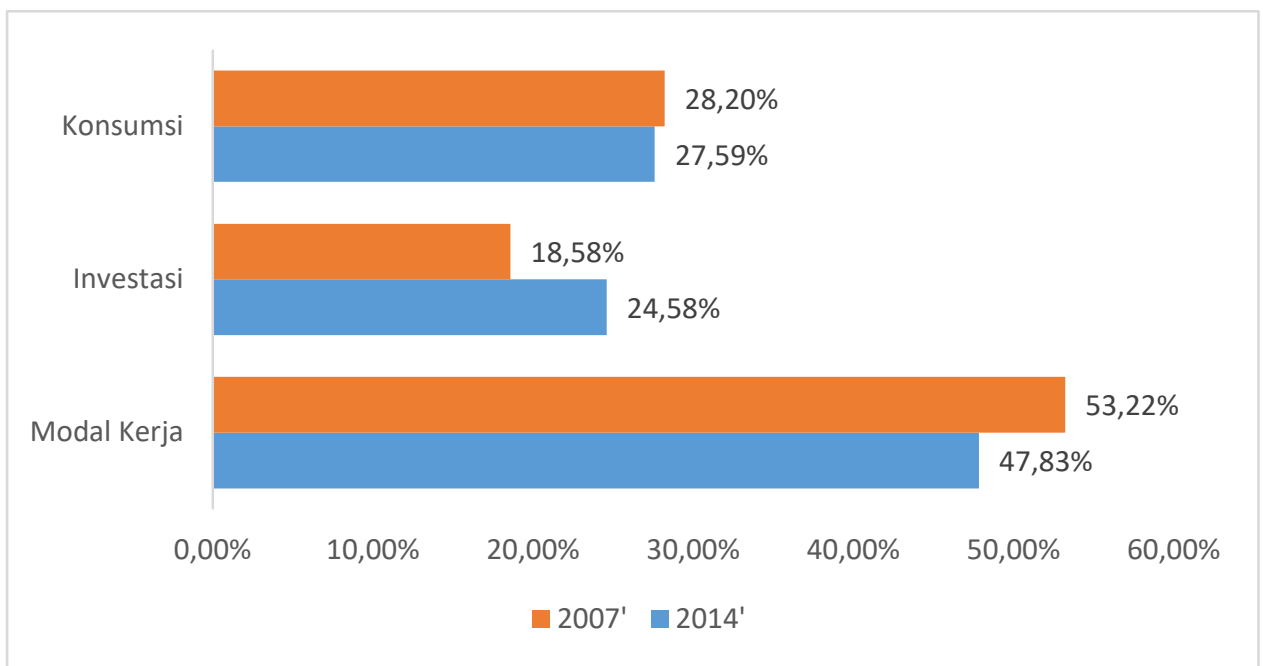

Source: Indonesian Banking Statistics (processed)

Based on the figure shown above, it is known that in 2007 the banking credit portion reached $53.22 \%$ and in 2014 reached $47.83 \%$. This portion is much larger if it is compared with the portion of credit in purpose of consumption and investment. The large portion of credit as working capital has contributed to the increase in the amount of people's income that utilizes credit and investment services from banks.

Furthermore, this research also found that savings/investments have a significant influence on household income. This is because the deposit interest rate determined by Bank Indonesia in the period of December 2014 was still relatively good at $5.75 \%$. According to a press release from Bank Indonesia in December 2014, the Bank Indonesia Board of Governors Meeting on December 11, 2014 decided to keep the BI rate at $7.75 \%$, with the lending facility and deposit facility interest rates remaining at 8,00\% and $5.75 \%$ (www.bi.go.id, 2014). Competitive interest rates on deposits and security in transactions cause people to like investing and keeping their funds organized.

In the study of Islamic economics, each person is encouraged to try and conduct real economic activities or muamalah activities. This is explained in sura At-Taubah verse 105, namely:

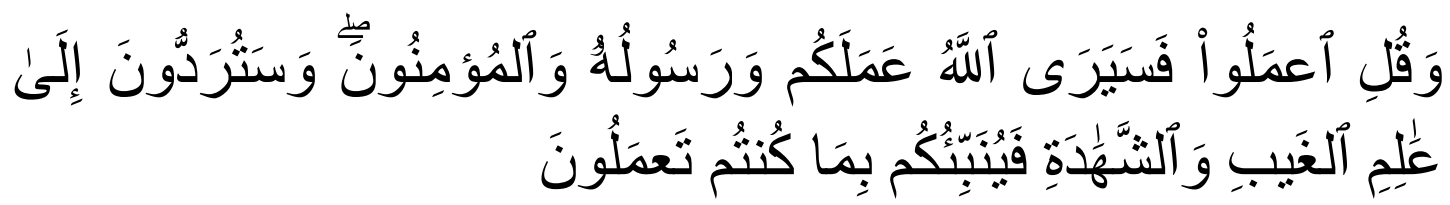


Impact of Financial Inclusion for Welfare : Analyze to Household Level

It means: "And say (unto them): "Act! Allah will behold your actions, and (so will) His messenger and the believers, and ye will be brought back to the Knower of the Invisible and the Visible, and He will tell you what ye used to do".

Based on that verse, it can be understood that every human being is required to work in order to meet his needs. Economic activities can be either buying and selling (bai), rent (ijarah) or cooperation/sharing (syirkah). In sharia financial institutions, the three principles are used to create various financial services products so that people can continue to utilize the products of financial institutions to conduct business activities, increase revenue and then pursue the welfare of their life.

\section{C.3. The Influence of Credit Amount and Savings/Investment on Household Consumption Expenditure}

The result of research on the influence of credit/financing and saving/investment on households consumption expenditure shows that there is significant influence of credit/financing on household consumption expenditure. It is seen from regression coefficient value of 0,062 and significance level of $0,002(\mathrm{p}<0,05)$. This means that when households utilize credit facilities from financial institutions, it will significantly increase household consumption expenditure. Furthermore, this study also found that there is a significant influence of saving/investment on household consumption expenditure. This is evidenced by the regression coefficient value of 0.016 and the significance level of 0.000 ( $\mathrm{p}<0.05)$. This means that when people make deposits or investments into financial institutions, then it will have a significant impact on household consumption.

The results of this study are in accordance with research conducted by Setyari (2012), Ugwuanyi (2012), Sengsourivong and Mieno (2014) who found that there is a significant influence of credit and investment on public expenditure. Consumption is generally defined as the use of goods and services that will directly meet human needs. Consumption as the household's expenditure on goods and final services in order to meet physical and spiritual needs. People who take advantage of credit facilities and investments from financial institutions, will get additional revenue from businesses and new assets they have. When income increases, consumption spending will also increase. This is in line with the theory put forward by James Dusenberry that public consumption expenditure is determined primarily by the high of highest income ever achieved. If revenue decreases, consumers will not reduce much of their spending on consumption. In order to maintain a 
Journal of Finance and Islamic Banking $\mid$ Vol. 1 No. 2, July-December 2018

high level of consumption, it is forced to reduce the amount of savings (Reksoprayitno, 2000).

In the study of Islamic economics, consumption activity undertaken to pursue prosperity required the role of faith. The role of faith becomes an important benchmark because it provides a world-view that tends to affect the human personality, that is in the form of behavior, lifestyle, taste, attitudes toward fellow human beings, resources, and ecology. In this context it is discussed about the disallowance of israf or exaggeration. The limit of consumption in Islam is contained in the Qur'an Surah Al-Furqan verse 67, it is:

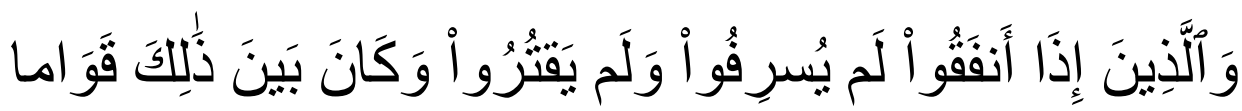

It means: "And those who, when they spend, are neither prodigal nor grudging; and there is ever a firm station between the two".

In that surah, human being is suggested to always spend the property with a reasonable dose, in which should not be exaggeration and not too stingy. The behavior of israf is forbidden even if the commodity spent is halal. Nevertheless, Islam still allows a Muslim to enjoy the gift of life, as long as it is still within reasonableness.

\section{C.4. The Influence of Credit Amount and Deposits/Investment on Residential Facilities}

Based on the results of research, it is obtained the result that credit/financing has no significant impact on housing facilities. It is seen from the regression coefficient of 0.024 and the significance level of 0.861 ( $p>0.05$ ). Furthermore, it was found that saving/investment did not have significant influence on residence facility as proved by regression coefficient value equal to 0,013 and significance level 0,893 ( $p>0,05$ ). The results of this research means that the credit/financing and savings/investment facilities utilized by households in the previous period did not have a significant impact on the improvement of residential facilities in the period thereafter. The results of this research are in contra to the research conducted by Sengsourivong and Mieno (2014) who found the impact of Credit and Saving Union (CSU) on increasing the number of household assets in Laos.

Insignificant credit/financing given by the financial institution with the value of the facility owned by the household, due to the obligation to pay the present purchased product with the future income. This is as explained by Suparmoko (2001) that credit/financing 
Impact of Financial Inclusion for Welfare : Analyze to Household Level

causes households to buy goods at present and their payments are made in the future, but it does not mean that the existence of credit facilities causes households to purchase more goods, because what they buy now must be paid with future income.

The same thing is applied for the people with savings/investment facilities from financial institutions. Savings or output from investments in these financial institutions, only being used by households to meet the basic needs of their life as for consumption and other things. This thing resulted savings/investments in financial institutions had no significant impact on the increasing of household facilities value.

In the study of Islamic economics, the satisfaction of the consumed products in this case household facilities, is measured by using the term "maslahah". According to Imam Syathibi, maslahah is the nature or ability of goods and services that support the basic elements and goals of human life on earth. These five basic elements are life or soul $(a l$-nafs), property or treasure (al-mal), belief (al-din), intellectual (al-aql), and family or descendants (al-nasl) (Fauzia and Riyadi, 2014). All goods and services that support the achievement and preservation of these elements in each individual, is called maslahah. Economic activities consist of production, consumption and exchange concerning the maslahah should be done as a worship in which its purpose is not only the satisfaction in the world but also the prosperity in the afterlife.

\section{CONCLUSION}

Based on the results of analysis and discussion, then the conclusion in this research are:

1. There is a positive and significant influence of credit amount/financing on household income. It is seen from the regression coefficient value of 0.164 and significance level of 0.00 ( $\mathrm{p}<0.05)$. This research found that there is a positive and significant influence of saving/investment on household income. This is evidenced by the regression coefficient value of 0.110 and the significance level of $0.000(p<0.05)$.

2. There is a significant influence of credit amount/financing on household consumption expenditure. This is seen from the regression coefficient value of 0.091 and the significance level of $0.000(\mathrm{p}<0.05)$. Furthermore, this study also found that there is a significant influence of saving/investment on household consumption expenditure. This is evidenced by the regression coefficient value of 0.062 and the significance level of $0.000(\mathrm{p}<0.05)$. 
Journal of Finance and Islamic Banking | Vol. 1 No. 2, July-December 2018

3. Credit/financing has no significant impact on housing facilities. It is seen from the regression coefficient of 0.024 and the significance level of 0.861 ( $p>0.05$ ). Furthermore, it was found that saving/investment does not have significant influence on residence facilities as evidenced by regression coefficient value of 0.013 and significance level of $0.893(\mathrm{p}>0.05)$.

\section{Reference}

Anto, Hendrie. 2003. Pengantar Ekonomika Mikro Islam. Yogyakarta.

Badawi, Ahmad Zaki. 1982. Mu'jam Mushthalahâtu al-'Ulûm al-Ijtimâ'iyyah. Beirut, Maktabah Lubnan: New Impression.

Bank Indonesia. 2014. Booklet Keuangan Inklusif. Departemen Pengembangan dan Akses Keuangan dan UMKM.

BPS. 2005. Indikator Kesejahteraan Rakyat. Jakarta: BPS

Boediono. 2002. Ekonomi Mikro Seri Sinopsis: Pengantar Ilmu Ekonomi No.1. Yogyakarta : BPFE.

Fauzia, I Yunia and Riyadi, A Kadir. 2014. Prinsip Dasar Ekonomi Islam Perspektif Maqashid al-Syari'ah. Kencana Prenadamedia Group.

Gujarati, Damodar. 2003. Ekonometrika Dasar, Edisi Kelima, alih bahasa Zain Sumarno. Jakarta: Erlangga

Hafiduddin, Didin. 2002. Zakat dalam Perekonomia Moderen. Jakarta: Gema Insani

Mishkin, Frederic S. 2008. Ekonomi Uang, Perbankan, dan Pasar Keuangan. edisi 8. Jakarta: Salemba Empat.

Miraza, Bahctiar Hassan. 2014. Membangun Keuangan Inklusif. Jurnal Ekonomi Manajemen dan Akuntansi. Vol. 23. No 2.

Norman, Azhari. 2010. Analisis Pengaruh Financial Deepening pada Sektor Perbankan dan Pasar Modal Terhadap Pertumbuhan Ekonomi Indonesia. Tesis. Universitas Indonesia. Jakarta.

Okereke, Samuel Felix. 2011. An Econometric Analysis of The Impact of Financial Deepening on Aggregate Welfare in Nigeria. Tesis. University of Nigeria.

Reksoprayitno, Soediyono, 2000. Ekonomi Makro. Yogyakarta : BPFE.

Sengsourivong, Kongpasa dan Mieno, Fumiharu. 2014. Impacts of Savings and Credit Union Programs on Household Welfare in Laos: Case Study of the Vientiane Vicinity during the mid-2000s. PRIMCED Discussion Paper Series, No. 55. 
Setyari, Ni Putu Wiwin. 2012. Evaluasi dampak Kredit Mikro Terhadap Kesejahteraan Rumah Tangga di Indonesia: Analisis Data Panel. Jurnal Ekonomi Kuantitatif Terapan. Vol 5 No 2.

Suparmoko, M. 2001. Ekonomi Publik, Untuk Keuangan dan Pembangunan Daerah, Edisi Pertama, Yogyakarta : Andi.

Ugwuanyi, Hillary Chigozie. 2012. Access to and Impact of Credit on Households Welfare in Nigeria. International Journal Of Research In Commerce, Economics \& Management. Volume No. 3. 